This item was submitted to Loughborough's Research Repository by the author.

Items in Figshare are protected by copyright, with all rights reserved, unless otherwise indicated.

\title{
Single cell tracking of gadolinium labeled CD4(+) T cells by laser ablation inductively coupled plasma mass spectrometry
}

PLEASE CITE THE PUBLISHED VERSION

http://dx.doi.org/10.1021/ac4022715

PUBLISHER

(c) American Chemical Society

VERSION

AM (Accepted Manuscript)

LICENCE

CC BY-NC-ND 4.0

\section{REPOSITORY RECORD}

Managh, Amy J., Sheldon L. Edwards, Andrew Bushell, Kathryn J. Wood, Edward K. Geissler, James A. Hutchinson, Robert W. Hutchinson, Helen J. Reid, and Barry L. Sharp. 2019. "Single Cell Tracking of Gadolinium Labeled CD4(+) T Cells by Laser Ablation Inductively Coupled Plasma Mass Spectrometry". figshare. https://hdl.handle.net/2134/16069. 


\section{Single cell tracking of gadolinium labelled $\mathrm{CD}^{+} \mathrm{T}$ cells by laser ablation inductively coupled plasma mass spectrometry (LA-ICP-MS)}

Amy J. Managh, ${ }^{a}$ Sheldon L. Edwards, ${ }^{b}$ Andrew Bushell, ${ }^{b}$ Kathryn J. Wood, ${ }^{\mathrm{b}}$ Edward K. Geissler, ${ }^{c}$ James A. Hutchinson, ${ }^{c}$ Robert W. Hutchinson, ${ }^{d}$ Helen J. Reid ${ }^{a}$ and Barry L. Sharp ${ }^{a}$

${ }^{a}$ Centre for Analytical Science, Department of Chemistry, Loughborough University, Loughborough, Leicestershire, LE11 3TU, UK.

${ }^{b}$ Nuffield Department of Surgical Sciences, University of Oxford, John Radcliffe Hospital, Headington, Oxford, OX3 9DU, UK.

C Division of Experimental Surgery, Department of Surgery, University Hospital Regensburg, Regensburg, 93053, Germany.

Electro Scientific Industries, 8 Avro Court, Ermine Business Park, Huntingdon, Cambridgeshire, PE29 6XS, UK.

Key words: Laser ablation; ICP-MS; T cells; Gd-DTPA-BMA; Gd-DOTA; MRI contrast agents; single cell; tracking.

\section{ABSTRACT}

Cellular therapy is emerging as a promising alternative to conventional immunosuppression in the fields of haematopoietic stem cell (HSC) transplantation, autoimmune disease and solid organ transplantation. Determining the persistence of cell-based therapies in vivo is crucial to understanding their regulatory function and requires the combination of an extremely sensitive detection technique and a stable, long-lifetime cell labelling agent. This paper reports the first application of laser ablation inductively coupled plasma mass spectrometry (LA-ICP-MS) to perform single cell detection of $T$ cell populations relevant to cellular immunotherapy. Purified human $\mathrm{CD}^{+} \mathrm{T}$ cells were labelled with commercially available Gd-based MRI contrast agents, Omniscan ${ }^{\circledR}$ and Dotarem $₫$, which enabled passive loading of up to $10^{8} \mathrm{Gd}$ atoms per cell. In mixed preparations of labelled and unlabelled cells, LA-ICP-MS was capable of enumerating labelled cells at close to the predicted ratio. More importantly, LA-ICP-MS single cell analysis demonstrated that the cells retained sufficient label to remain detectable for up to 10 days post-labelling both in vitro and in vivo in an immunodeficient mouse model. 


\section{INTRODUCTION}

Cellular therapy with defined populations of regulatory immune cells is emerging as a clinically viable strategy to augment or replace conventional immunosuppression in the fields of haematopoietic stem cell (HSC) transplantation, autoimmune disease and solid organ transplantation where the major driver is improved therapy and a reduction in drug toxicities. Much of the optimism surrounding these approaches is based on data from a large number of diverse animal models which show unequivocally that cellular therapy can take advantage of endogenous regulatory mechanisms in the mammalian immune system.

Phase I/II clinical trials have evaluated naturally occurring regulatory $T$ cells ( $\mathrm{nTreg}$ ), in the context of graft-versus-host-disease (GVHD), a life-threatening complication of HSC transplantation ${ }^{1-3}$ and in paediatric patients with new-onset Type 1 diabetes. ${ }^{4}$ In solid-organ transplantation, an international consortium is currently seeking regulatory approval for the evaluation of several types of regulatory immune cells in living-donor kidney transplantation. Cell types under investigation in this study will include nTreg, ${ }^{5-7} \mathrm{Tr} 1 \mathrm{cells}^{8,9}$ dendritic cells, ${ }^{10}$ and macrophages. ${ }^{11,12}$

Determining the persistence and tissue distribution of the administered cells is essential for assessing their immunoregulatory effects in vivo but tracking therapeutic cells presents two significant challenges. Firstly, in the majority of cases, the cellular therapy will be derived from the transplant donor in HSC transplantation, or from the recipient in the case of kidney transplantation. Thus, in most cases the cells will be autologous with the immune system of the transplant recipient and therefore invisible to normal phenotypic methods of detection such as flow cytometry. Secondly, at current planned doses, the administered cells will represent a small fraction of the recipient's endogenous regulatory immune cells adding further to the problem of detection. A solution to these two related problems would be the development of clinically acceptable (GMP) cell labelling techniques combined with a sensitive detection method, capable of detection of single cells and at very high cell detection efficiency.

Contrast agents (CA) are frequently used in conjunction with clinical magnetic resonance imaging (MRI) to enhance the quality of images. These agents typically consist of a 
paramagnetic metal ion, such as $\mathrm{Gd}^{3+}$ or $\mathrm{Fe}^{2+} / \mathrm{Fe}^{3+}$, associated with a strong chelating ligand. ${ }^{13}$ Gadolinium based contrast agents are a particularly attractive option for cell labelling, due to their low background levels in the human body, and indeed several studies have reported their use as cellular labels for MRI tracking studies. ${ }^{14-16}$ However, whilst MRI is undoubtedly valuable for bulk imaging, the technique is currently incapable of providing the necessary sensitivity and spatial resolution for single cell monitoring.

Laser ablation inductively coupled plasma mass spectrometry (LA-ICP-MS) is a sensitive analytical technique, widely used for mapping the distribution of elements in complex biological samples. ${ }^{17}$ Examples include the analysis of copper and zinc in liver and kidney sections, ${ }^{18,19}$ the mapping of copper, zinc, iron and manganese in sections of brain tissue, ${ }^{20-}$ ${ }^{24}$ and the quantification of metal binding proteins in gels following electrophoretic separation of blood serum. ${ }^{25}$ Recently, the technique has been applied to image the distribution of iodine, silver and gold in single fibroblast cells, following labelling in vitro with $\mathrm{KI}_{3}$ and gold and silver nanoparticles respectively. ${ }^{26,27}$ Studies have also reported the detection of gadolinium-based contrast agents in tumour and tissue samples. ${ }^{28-30}$ Two of these investigations involved a direct comparison between LA-ICP-MS and MRI, and demonstrated the enhanced sensitivity and spatial resolution achievable when using LA-ICPMS. ${ }^{29,30}$

Although LA-ICP-MS clearly has remarkable sensitivity, application of this technique to cellular therapy depends upon cell labelling techniques that are likely to be approved for clinical use. In the current study, purified human $\mathrm{CD} 4^{+} \mathrm{T}$ cells were labelled with the contrast agents, Omniscan ${ }^{\circledR}$ (Gadolinium diethylenetriaminepentaacetic acid bismethylamide, GdDTPA-BMA) or Dotarem ${ }^{\circledR}$ (Gadolinium 1,4,7,10-tetraazacyclododecane-1,4,7,10tetracarboxylic acid, Gd-DOTA) that are both in routine clinical use in magnetic resonance imaging. We demonstrate that human $\mathrm{CD} 4^{+} \mathrm{T}$ cells and highly purified naturally occurring regulatory $T$ cells can be labelled efficiently with $\mathrm{Gd}$-chelates, and that the cells can then be readily detected in mixed populations using LA-ICP-MS. Importantly, both in vitro and in vivo, the cells retain detectable label for at least 10 days. To the authors' knowledge, this is the first application of LA-ICP-MS to track single gadolinium labelled human T cells. 


\section{EXPERIMENTAL}

\section{Instrumentation and operating parameters}

Analyses were performed on a sector-field ICP-MS instrument (Element 2XR, Thermo Scientific, Bremen, Germany). For solution analyses, the instrument was fitted with a cyclonic spray chamber (Glass Expansion, Victoria, Australia), a conical glass concentric nebuliser (Glass Expansion, Victoria, Australia), and a $0.25 \mathrm{~mm}$ I.D. probe (Elemental Scientific, Omaha, USA). For laser ablation, a UP-213 laser ablation system (Electro Scientific Industries, Cambridgeshire, UK) was coupled to the sector-field ICP-MS instrument. The laser system was fitted with a low-volume, tear-drop shaped cell, which has been described elsewhere. ${ }^{31}$ Helium was used as an ablation gas, at a typical flow rate of 0.6 $\mathrm{l} / \mathrm{min}$, with argon introduced through a Y-piece, at a flow rate of $0.8 \mathrm{l} / \mathrm{min}$, after the ablation cell. The system was tuned for maximum ${ }^{238} \mathrm{U}$ signal intensity, whilst keeping the $\mathrm{Th} / \mathrm{U}$ ratio to approximately 1 , during the ablation of NIST 611 glass. Typical operating conditions are given in Table 1.

\section{Cell culture and labelling}

Human peripheral blood mononuclear cells (PBMC) were isolated from a leukocyte cone obtained from a local blood bank. Leukocytes were enriched by Ficoll density gradient centrifugation, and $\mathrm{CD} 4^{+}$cells isolated ( $95-98 \%$ purity) by MACS positive selection (Miltenyi Biotec). To isolate defined populations to $>98 \%$ purity, cells were labelled with anti-CD4 (Beckman-Coulter clone SFCI2T4D11), anti-CD25 (BD Biosciences clone M-A251) and antiCD127 (BD Biosciences clone hIL-7R-M21) antibodies and flow-sorted on a BD FACSAria (BD Biosciences). After isolation, cells were plated at a density of $1 \times 10^{6}$ cells per well in 2 $\mathrm{ml}$ of RPMI 1640 medium, supplemented with $10 \%$ human albumin, penicillin, streptomycin and glutamine, plus $1 \times 10^{5} \mathrm{U} / \mathrm{ml}$ human recombinant IL-2 (Proleukin, Novartis). Each well also received a volume of either Gd-DTPA-BMA (Omniscan ${ }^{\circ}$, GE Healthcare, UK) or GdDOTA (Dotarem ${ }^{\circledR}$, Guerbet Laboratories, France). The cells were incubated overnight ( 16 hours) at $37^{\circ} \mathrm{C}$ in $95 \%$ air $/ 5 \% \mathrm{CO}_{2}$. Following the incubation period, the cells were washed extensively in PBS/ 2\% FCS to remove any unbound label. Cell viability was determined using a trypan blue assay. 


\section{Optimisation of the labelling dose and incubation time}

Labelling optimisation experiments for Gd-DOTA and Gd-DTPA were carried out in parallel using cells from the same donor. Cell culture and sample preparation were performed in accordance with the procedure detailed above. Quantification of label uptake by the cell population was determined using solution based ICP-MS. For this, cells were spun down into pellets and then digested according to the method proposed by Yamada et $a .^{32}$ and modified by Kerr. ${ }^{33}$ Briefly, this involved addition of $67 \% \mathrm{HNO}_{3}\left(100 \mu \mathrm{l}\right.$ per $1 \times 10^{6}$ cells $)$ and heating at $70^{\circ} \mathrm{C}$ for 1 hour, followed by addition of $30 \% \mathrm{H}_{2} \mathrm{O}_{2}\left(100 \mu \mathrm{l}\right.$ per $1 \times 10^{6}$ cells $)$ and heating at $70^{\circ} \mathrm{C}$ for a further 4 hours. The samples were then evaporated to dryness under a stream of nitrogen, and reconstituted in $2 \% \mathrm{HNO}_{3}$. A range of calibration standards were prepared by dilution of a $10 \mathrm{ppm}$ elemental standard solution (SPEX Certiprep Ltd., Middlesex, UK).

For the dose optimisation study, doses of 5, 10, 20, 50, 100 and $200 \mu \mathrm{l}$ of either Omniscan $®$ or Dotarem ${ }^{\circledR}$ were added to each well, prior to incubation overnight. This corresponds to $0.19,0.38,0.75,1.86,3.63$ and $6.72 \mathrm{mg} \mathrm{Gd} / \mathrm{ml}$, and $0.20,0.39,0.78,1.92,3.74$ and 7.15 $\mathrm{mg}$ of $\mathrm{Gd} / \mathrm{ml}$, for the Omniscan ${ }^{\circledR}$ and Dotarem ${ }^{\circledR}$ wells respectively. A total of three replicates were performed for each dose. In addition, three control wells containing cells without contrast agent were prepared. Following dose optimisation, the incubation time was varied using the optimum dose. Incubation times of $0,1,2,4,8$ and 16 hours were assessed in triplicate. The optimum dose and incubation time were then carried forward to subsequent experiments.

\section{Laser ablation of single cells}

For laser ablation-ICP-MS, labelled cells were plated onto slides (Thermo Superfrost, Thermo Scientific, UK) using a CytoSpin (Shandon Cytospin®, Thermo Scientific, UK). This was to ensure removal of the cell culture media and provide an even distribution of the cells across the slide, enabling single cell targeting. In addition to the slides containing labelled cells, control slides containing non-labelled $\mathrm{CD} 4^{+}$cells were also prepared. Each slide held approximately 50,000 cells. Single cell identification was demonstrated by ablating $25 \mu \mathrm{m}$ diameter areas at locations corresponding to cells. This size was chosen to ensure sampling of the complete cell, whilst minimising the chance of overlap onto neighbouring 
cells. Only single cells were targeted, cells present in clusters or closer than $25 \mu \mathrm{m}$ apart were disregarded. The presence or absence of label was determined from the ${ }^{157} \mathrm{Gd}$ signal.

To simulate biological samples, where labelled cells are present amongst a background of non-labelled cells, slides containing mixed labelled and non-labelled cells were prepared. For these, the relevant dilutions were made in solution before fixing the cells onto slides. Ratios of 1:1, 1:10 and 1:100 were prepared as known samples, and a replicate of each was provided as a blind sample. Blind samples were randomised and identified with a nondescriptive character. The expected ratios of these were not disclosed to the analyst until after the analysis was completed.

\section{In vivo and in vitro label retention}

In order to demonstrate cellular retention of the label and assess its potential for cell tracking studies, a 10 day in vivo mouse study was conducted. All mouse experiments were conducted in accordance with the Animals (Scientific Procedures) Act 1986. Human peripheral blood mononuclear cells (PBMC) were isolated from leukocyte cones. The CD4 ${ }^{+}$ component was isolated using the procedure described above, and these cells were labelled using the optimised labelling procedure. Following labelling, the $\mathrm{Gd}-\mathrm{CD} 4^{+}$cells were washed extensively and recombined with the non-CD4 ${ }^{+}$PBMC component. Re-mixing with the unlabelled PMBC component was found to be necessary to ensure viability of the cells in the host. The recombined cells were then injected intraperitoneally into BALB/C Rag-/common- $\gamma$ chain mice, at a level of 5 million cells per mouse. At 3,6 , and 10 days post infusion, the spleen and blood were harvested and a peritoneal lavage was performed. The extracted cells were plated onto slides for LA-ICP-MS analysis, using the CytoSpin method described above. Flow cytometry (BD FACSCanto, BD Biosciences) was used to determine the extent of human cell reconstitution.

To estimate the degree of signal loss caused by label leakage, an in vitro label retention study was performed in parallel to the in vivo mouse experiments, using cells from the same donor. For this, the cells were washed extensively after labelling and cultured for a further period in vitro before re-washing and plating onto slides. 


\section{RESULTS AND DISCUSSION}

\section{Label uptake and optimisation}

Figure 1 shows the impact of increasing the dose of gadolinium chelate on the uptake of $\mathrm{Gd}$ by human $\mathrm{CD}^{+}$cells. Uptake of $\mathrm{Gd}$ increased in a dose-dependent manner. A quadratic fit with a low second order term fitted the data; however no plateau was reached in the dose range examined. Despite the higher uptake at 100 and $200 \mu \mathrm{l}$, a dose of $50 \mu \mathrm{l}$ was chosen as the optimum (this corresponds to 1.86 and $1.96 \mathrm{mg} \mathrm{Gd} / \mathrm{ml}$ for Omniscan and Dotarem respectively). Volumes higher than $50 \mu$ occupied a significant portion of the $2 \mathrm{ml}$ culture medium, which could potentially cause osmotic effects. However, it should be pointed out that the cell viability was $96 \%$ or above for all doses tested.

Gadolinium uptake also increased as a function of incubation time for both complexes, as shown in Figure 1. The highest uptake was observed after 16 hours, which was used as the standard incubation time in all subsequent experiments. Longer incubation times were not tested on the grounds that they might have a detrimental effect on cell viability. As shown later, the labelling levels achieved were more than adequate for achieving $\sim 100 \%$ detection efficiency. A 0 hour time point was included in the study as a measure of the efficiency of the cell washing process. For this, the Gd complex was added to the well and the cells washed immediately, thereby allowing insufficient time for label internalisation. Consequently, any $\mathrm{Gd}$ found in these samples was taken to be from incomplete removal of the non-internalised complex and thus represents the background in the assay. The $\mathrm{Gd}$ content of the 0 hour samples ranged between 5 and 20 times larger than that in the nonlabelled controls. However, this figure represents only 0.7 and $3 \%$ of the final uptake achieved using the optimised labelling conditions for Gd-DTPA-BMA and Gd-DOTA respectively. The cell washing procedure was therefore considered sufficient to enable quantification of label uptake. The optimisation experiments, shown in Figure 1, indicated that Gd-DTPA-BMA provides higher net Gd loading than Gd-DOTA, with an average loading of $1.43 \times 10^{8}$ atoms per cell observed for Gd-DTPA-BMA compared to only $9.36 \times 10^{7}$ atoms per cell for Gd-DOTA at the optimised conditions. Therefore, Gd-DTPA-BMA was used in all subsequent experiments. 
It is likely that uptake of the Gd-complexes occurred predominately by pinocytosis, as has been reported for other cell lines. ${ }^{34,35}$ Gadolinium internalised via this route is known to localise to endosomes within the perinuclear region of the cell, ${ }^{34}$ where subsequent detachment of $\mathrm{Gd}^{3+}$ from its chelate may occur. ${ }^{35}$ Dechelation is expected to be more prevalent for Omniscan than Dotarem. As shown in Figure 2, the DTPA-BMA chelate is nonionic and has an open chain structure, hence providing less stable binding to $\mathrm{Gd}^{3+}$ than the macrocylic, ionic DOTA chelate. ${ }^{36}$ Dechelation is accelerated in the presence of phosphate or competing cations, ${ }^{37}$ both of which are constituents of the cell culture media. Thus it is likely that by the 16 hour time point, a portion of the $\mathrm{Gd}$ in the culture media was also present as free rather than complexed $\mathrm{Gd}$. Free $\mathrm{Gd}^{3+}$ ions may be subject to a different route of uptake than the complexed form. In 1999, Cheng et al. conducted a comprehensive study into the uptake of lanthanide $3+$ ions by erythrocytes. ${ }^{38} \mathrm{Gd}^{3+}$ was found to bind initially to membrane phospholipids, followed by a transfer to membrane proteins. This process induced conformational changes in the membrane, which resulted in the formation of pores, facilitating the entry of $\mathrm{Gd}^{3+}$. It is possible that this mechanism may have provided an additional route for $\mathrm{Gd}$ uptake. Since Gd-DTPA-BMA is known to be more unstable than Gd-DOTA, this additional route may account for the differences between Gd uptake for the two chelates, particularly at the 16 hour time point.

The data shown in Figure 1 was obtained using cells isolated from human PBMC by magnetic negative selection of $\mathrm{CD}_{1}{ }^{+} \mathrm{B}$ cells and $\mathrm{CD} 14^{+}$monocytes followed by CD4 positive selection. Phenotypic analysis showed that the resultant populations were between 95-98\% CD4 ${ }^{+} \mathrm{T}$ cells, but they also contained $\sim 2-5 \%$ monocytes due to low level monocyte expression of CD4. In view of the fact that these cells are known to have very active phagocytic and pinocytic pathways, the possibility that the Gd labelling seen was due to preferential monocyte uptake could not be ruled out. To address this question, human CD4 ${ }^{+}$ $\mathrm{T}$ cells were purified by flow sorting to purities exceeding $99 \%$, containing $<0.2 \%$ CD $14^{+}$ monocytes (data not shown). The resultant populations were then labelled using the optimised Gd-DTPA-BMA protocol described above. Subsequent analysis showed a gadolinium uptake of $4.53 \times 10^{7}$ atoms per cell for $99.6 \%$ pure $\mathrm{CD} 4^{+} \mathrm{T}$ cells, compared with the $1.43 \times 10^{8}$ atoms per cell seen for the lower purity ( 95-98\%) CD4 ${ }^{+} \mathrm{T}$ cells.

Most of the initial focus on regulatory immune cell therapy cellular therapy has been and will continue to be on naturally occurring Treg (nTreg) ${ }^{5-7}$ Although these cells represent only $\sim 5-10 \%$ of $\mathrm{CD}^{+} \mathrm{T}$ cells in human peripheral blood, the actual proportion and function varies 
considerably between individuals. To determine the likely variability in $\mathrm{Gd}$ labelling of functional nTreg, human $\mathrm{CD} 4^{+} \mathrm{CD} 25^{+} \mathrm{CD} 127^{\mathrm{lo}} \mathrm{T}$ cells were flow sorted from three different individuals using a sort strategy known to isolate nTreg with high functional activity both in vitro and in humanised mouse models. ${ }^{39,40}$ The resultant populations (purity 97.9\%, 98.5\% and $98.1 \%$, donors 1-3 respectively) were then labelled with the optimised Gd-DTPA-BMA protocol and analysed as described. The labelling of these nTreg showed remarkable consistency with $5.06 \times 10^{7}, 5.08 \times 10^{7}$ and $5.88 \times 10^{7} \mathrm{Gd}$ atoms per cell detected from donors $1-3$ respectively.

The above data show unequivocally that populations of non-phagocytic human $\mathrm{T}$ cells being considered for cellular therapy can be labelled with gadolinium chelates thus offering a potential approach for therapeutic $T$ cell tracking. However, determining the persistence of gadolinium-labelled $T$ cells in accessible tissues such as the peripheral blood is potentially compromised by the presence of highly phagocytic cells such as granulocytes, neutrophils and monocytes. Positive selection on the basis of CD4 would allow enrichment of populations likely to contain administered nTreg but as described above, monocytes would present a problem since they might phagocytose gadolinium from dying circulating $T$ cells, thereby giving false positives. Although flow sorting to $>99 \% \mathrm{~T}$ cell homogeneity is a valuable research approach, cell losses would preclude this as a diagnostic strategy. Therefore, laser ablation-ICP-MS was evaluated for the ability to identify labelled targets at a single cell level where the ablation of specific, individual cells could provide a key advantage not available from solution analysis.

\section{Laser ablation of single cells}

Human $\mathrm{CD}^{+} \mathrm{T}$ cells were purified by positive selection (final purity, 97.2\%) and labelled with Gd-DTPA-BMA as described. Unlabelled cells cultured for $16 \mathrm{hrs}$ in the presence of IL-2 served as a negative control. Figure 3 shows the ${ }^{157} \mathrm{Gd}$ signal intensities for the ablation of 25 individual labelled cells (A) and 25 individual unlabelled cells (B) after deposition onto slides by centrifugation. Distinct signals were observed for the ablation of the labelled cells, compared to only background noise for their non-labelled counterparts. The $25 \mu \mathrm{m}$ spot size and $\sim 9 \mathrm{~J} \mathrm{~cm}^{-2}$ fluence used in these experiments ensured complete ablation of each $\sim 10 \mu \mathrm{m}$ cell in less than a second. Therefore, each signal observed can be regarded as representative of the total amount of $\mathrm{Gd}$ per individual cell. Figure 4 is a histogram showing the variation in label uptake observed when ablating 1000 individual labelled cells taken from 
the same labelled population as used in Figure 3. For this, the ${ }^{157} \mathrm{Gd}$ signal intensities were grouped into classes, with the number of occurrences for each class plotted on the y-axis. Of the 1000 cells ablated, 998 gave clear signals, confirming uptake of Gd by human CD4 ${ }^{+} \mathrm{T}$ cells. In the range of $0-1.5 \times 10^{4}$ counts the distribution of signals was approximately Gaussian, with a RSD of $39 \%$. A small percentage (1.6\%) of signals occurred outside this region. These higher signals are likely to correspond to the ablation of monocytes. Accordingly, the number of high signals observed matches closely with the proportion of contaminating $\mathrm{CD} 14^{+}$monocytes $(2.8 \%)$ in the input cell population.

Application of the technique to cell tracking requires discrimination of labelled cells from a background of non-labelled cells. In a demonstration experiment, labelled $\mathrm{CD} 4^{+} \mathrm{T}$ cells were mixed with non-labelled $C D 4^{+} \mathrm{T}$ cells in various ratios, prior to analysis by LA-ICP-MS. As shown in Table 2, the percentage labelled as determined by LA-ICP-MS matched well with the prepared ratios with differences probably accounted for by a combination of incomplete mixing and pipetting errors. As a further test of the technique, blind ratios of labelled and unlabelled $\mathrm{CD}^{+} \mathrm{T}$ cells were prepared and the blinding only revealed after LA-ICP-MS analysis. As shown in Table 2, ratios observed from the blind experiments corresponded with the expected ratios adding further confirmation to the reliability of the technique.

\section{In vivo and in vitro label retention}

In addition to detection, a second key characteristic for any label considered for in vivo cell tracking is label retention. Therefore, Gd-DTPA-BMA labelled $\mathrm{CD} 4^{+} \mathrm{T}$ cells were cultured in vitro in gadolinium-free $T$ cell growth medium containing IL-2 and samples taken daily for LAICP-MS analysis. As shown in Table 3, although the average signal intensities fell with time, reaching roughly $50 \%$ of the day 1 value after 10 days, the label remained detectable at all time points examined, with $98.8 \%$ of cells retaining sufficient $\mathrm{Gd}$ for detection up to 10 days in culture. In view of the low background signals observed for non-labelled cells, it seems likely that $\mathrm{Gd}$ labelled cells should be detectable for periods well beyond 10 days.

Although in vitro label retention is encouraging, a more important question with respect to cellular therapy is whether cells retain a gadolinium signal in vivo. To address this question we took advantage of a well characterised humanised mouse model in which immunodeficient BALB/C mice lacking $T$ cells, $B$ cells and functional NK cells are 
reconstituted with defined populations of human immune cells. ${ }^{39}$ These double knock-out (DKO) mice were reconstituted intra-peritoneally with $2 \times 10^{6} \mathrm{Gd}-\mathrm{DTPA}-\mathrm{BMA}$ labelled $\mathrm{CD} 4^{+} \mathrm{T}$ cells together with $3 \times 10^{6}$ autologous PBMC which aid $\mathrm{T}$ cell reconstitution by providing essential $T$ cell growth and survival factors. At 3, 6 and 10 days after reconstitution, the mice were killed for recovery of the peritoneal lavage, spleen and blood. Reconstitution in this model is defined as $>1 \%$ human $\mathrm{CD} 45^{+}$cells in the leucocyte gate as determined by flow cytometry. ${ }^{39}$ In agreement with previous experience of this model which showed that reconstitution of spleen and blood lags behind that of the peritoneal lavage, human cells were not found in the spleen or blood up to day 10 (not shown). However, human CD45 cells were readily detected in the peritoneal lavage. Example data for one of three mice harvested 6 days after cell administration is shown in Figure 5A. For comparison, the lower histogram shows an example of non-reconstitution. As shown in the lower dot plot, region $\mathrm{P} 3$ confirms the presence of human $\mathrm{CD} 4^{+} \mathrm{T}$ cells within the human $\mathrm{CD} 45^{+}$gate.

Aliquots of each lavage sample were plated without cell purification onto slides for LA-ICPMS analysis. Figure 5B shows an LA-ICP-MS plot from the lavage sample in Figure 5A showing identification of 5 gadolinium labelled cells. It is notable that whilst cells analysed after in vitro culture were relatively uniform in size, those examined from the lavage samples contained significant numbers of blasting cells possibly representing $\mathrm{T}$ cells mounting a xenogeneic graft-versus-host response. To accommodate the larger cell diameters, the ablation spot size was increased from 25 to $30 \mu \mathrm{m}$. However, increasing the spot size made the selection of single cells more challenging and it is possible that some of the low signals in Figure 5B were caused by slight overlap of the ablated region with the edges of neighbouring labelled cells. To account for the low signals, a threshold value was set at $5 \%$ of the average signal intensity of the corresponding in vitro sample. Signals below this threshold were not included in the \% labelled count.

Table 4 summarises the in vivo Gd retention data for day 3, day 6 and day 10 following the administration of labelled $\mathrm{CD}^{+} \mathrm{T}$ cells and shows the percentage of labelled cells found in the mouse lavage samples. In each case the detection of $\mathrm{Gd}$ labelled cells by LA-ICP-MS correlated with the presence of human $\mathrm{CD} 4^{+} \mathrm{T}$ cells in the lavage. Furthermore, at the last time point examined when only two mice were available (day 10), both showed clear reconstitution and gadolinium positive cells were unambiguously detected (Table 4). Thus, both the in vitro and the in vivo data indicate that, when labelled with Gd-DTPA-BMA, human $\mathrm{CD} 4^{+} \mathrm{T}$ cells retain a detectable gadolinium level for at least 10 days. 


\section{Nephrogenic systemic fibrosis}

The potential use of gadolinium labelling for tracking immune cellular therapies would depend on a favourable toxicity profile for the label itself and while Gd-chelates are widely used in clinical MRI, one significant complication of in vivo gadolinium administration is Nephrogenic systemic fibrosis (NSF). Although rare, this condition is potentially fatal and is characterised by "extensive thickening and hardening of the skin". ${ }^{41}$ Studies on patients with impaired renal function have found a link between the intra-venous administration of gadolinium chelates and the onset of NSF. ${ }^{42,43}$ Consequently, the administration of gadolinium contrast agents for MRI imaging is contra-indicated in patients with renal impairment. Thus, any proposed use of gadolinium labelling should be treated with caution, particularly since regulatory approval is currently being sought for cellular therapy in renal transplant patients. ${ }^{44}$ However, it is important to note that at the anticipated cell doses used in this study $\left(3 \times 10^{6} / \mathrm{kg}\right.$ patient body weight), the $\mathrm{Gd}$ exposure from the proposed labelling method is dramatically lower than that received during a typical MRI scan. When taking into account the average cell uptake shown in the current study of $\sim 27 \mathrm{fg}$ and the anticipated cell dose, the likely Gd exposure from cell labelling is $\sim 81 \mathrm{ng} / \mathrm{kg}$. This is over 100,000 times lower than the $15.2 \mathrm{mg} / \mathrm{kg}$ dose employed for MRI imaging (Omniscan is typically administered at a level of $0.2 \mathrm{ml}$ per $\mathrm{kg}$ patient weight; the formulation contains $287 \mathrm{mg} / \mathrm{ml}$ Gd-DTPA-BMA, which equates to $76.1 \mathrm{mg} / \mathrm{ml} \mathrm{Gd}$ ). The risk is further minimised due to the route of administration, since for cell labelling, the gadolinium chelates are essentially compartmentalised inside the cells rather than being introduced into the systemic circulation.

\section{CONCLUSION}

This paper represents the first application of LA-ICP-MS to perform single cell tracking of therapeutically administered cells. The technique was demonstrated on an immunodeficient mouse model, where the Gd-DTPA-BMA label allowed discrimination of human $\mathrm{CD} 4^{+}$cells for up to 10 days post-administration. A working dose of $50 \mu$ Omniscan / $2 \mathrm{ml}$ well $(1.86 \mathrm{mg}$ $\mathrm{Gd} / \mathrm{ml}$ ) was used for cell labelling, which was based on sufficiency for cell tracking. However, since Gd cell content decreases with each cell division, it may be beneficial to increase this dose when performing longer term tracking experiments. Doses of up to $200 \mu \mathrm{l}$ Omniscan $(6.72 \mathrm{mg} \mathrm{Gd} / \mathrm{ml})$ were utilised during the solution study without noticeable impact 
on cell viability. Assessment of the effect of Gd-DTPA-BMA on the regulatory function of T cells will be the subject of a future study.

The detection method has several advantages over other cell tracking techniques. Firstly, elemental imaging does not rely on stable binding of $\mathrm{Gd}^{3+}$ to the chelate, thus the label can be detected at periods where its enhancement on MRI relaxation would be lost. Secondly, the use of laser ablation allows single cell targeting, removing interferences from other artifacts. Thirdly, the superior detection capability of sector field ICP-MS allows detection at levels of $10^{7}$ atoms per cell and below, compared to the value of $10^{8}$ atoms per cell recently reported for molecular mass spectrometry. ${ }^{35}$ With improved instrumentation, which will be described in another paper, and the use of higher efficiency mass spectrometers, it should be possible to improve this detection limit by 2-3 orders of magnitude. A further advantage of the technique is that if combined with fluorescently labelled antibody staining, it would be possible to target ablation to specific and defined cell subsets in a sample of peripheral blood or tissue biopsy and provide semi-quantitative data. If applied to the tracking of Gdlabelled $\mathrm{CD} 4^{+} \mathrm{CD} 25^{+} \mathrm{nTreg}$ in vivo, it would thus be possible to define the proportion of cell therapy $\mathrm{nTreg}$ within the total $\mathrm{CD} 4^{+} \mathrm{T}$ cell compartment. If immune cellular therapy is to progress beyond the current Phase I/II trials, such quantification will probably prove to be essential.

\section{ACKNOWLEDGEMENTS}

Support received from the ONE Study, a European Commission Seventh Framework Program funded project (EU FP7-HEALTH 'The ONE Study', Project reference 260687), is gratefully acknowledged. 
TABLES

Table 1. Typical operating conditions for ICP-MS and LA-ICP-MS analyses.

\begin{tabular}{|c|c|c|}
\hline Parameters & ICP-MS & LA-ICP-MS \\
\hline ICP radio frequency (RF) power & $1215 \mathrm{~W}$ & $1260 \mathrm{~W}$ \\
\hline Cool gas flow rate & $15.501 \mathrm{~min}^{-1}$ & $15.501 \mathrm{~min}^{-1}$ \\
\hline Auxiliary gas flow rate & $0.95 \mathrm{I} \mathrm{min}^{-1}$ & $0.95 \mathrm{I} \mathrm{min}^{-1}$ \\
\hline Sample gas flow rate & $0.901 \mathrm{~min}^{-1}$ & $0.801 \mathrm{~min}^{-1}$ \\
\hline Sample uptake rate & $\sim 70 \mu \mathrm{l} \mathrm{min}{ }^{-1}$ & - \\
\hline Torch x position & $3.9 \mathrm{~mm}$ & $5.2 \mathrm{~mm}$ \\
\hline Torch y position & $3.0 \mathrm{~mm}$ & $2.9 \mathrm{~mm}$ \\
\hline Torch z position & $-2.5 \mathrm{~mm}$ & $-1.9 \mathrm{~mm}$ \\
\hline Ablation gas flow & - & $\mathrm{He}, 0.60 \mathrm{I} \mathrm{min}^{-1}$ \\
\hline Laser spot size & - & $25-30 \mu \mathrm{m}$ \\
\hline Repetition frequency & - & $1 \mathrm{~Hz}$ (single shot) \\
\hline Laser power setting & - & $50 \%$ \\
\hline Laser fluence & - & $8.97 \mathrm{~J} \mathrm{~cm}^{-2}$ \\
\hline
\end{tabular}

Table 2. The percentage of Gd labelled cells observed when performing single cell LA-ICPMS on slides containing various ratios of $\mathrm{Gd}$ labelled to non-labelled human $\mathrm{CD} 4^{+} \mathrm{T}$ cells. Labelled cells were identified on the basis of their ${ }^{157} \mathrm{Gd}$ signal. 1000 cells were ablated per sample.

\begin{tabular}{|c|c|c|c|}
\hline & $\begin{array}{l}\text { Labelled : Non- } \\
\text { labelled ratio }\end{array}$ & $\begin{array}{c}\text { \% labelled cells } \\
\text { identified }\end{array}$ & $\begin{array}{c}\% \text { labelled cells } \\
\text { expected }\end{array}$ \\
\hline \multirow{5}{*}{ 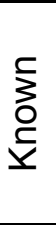 } & $1: 0$ & 99.8 & 100 \\
\hline & $1: 1$ & 39.6 & 50 \\
\hline & 1:10 & 5.5 & 9.1 \\
\hline & $1: 100$ & 0.6 & 1 \\
\hline & $0: 1$ & 0.1 & 0 \\
\hline \multirow{3}{*}{ 음 } & $1: 1$ & 39.1 & 50 \\
\hline & $1: 10$ & 5.2 & 9.1 \\
\hline & $1: 100$ & 0.7 & 1 \\
\hline
\end{tabular}


Table 3. The number of $\mathrm{Gd}$ labelled human $\mathrm{CD} 4^{+}$cells observed after various periods of in vitro culture, following labelling with the $\mathrm{Gd}$ chelate Omniscan®. Individual cells (250 per sample) were analysed by LA-ICP-MS. Labelled cells were identified on the basis of their ${ }^{157} \mathrm{Gd}$ signal.

\begin{tabular}{ccc}
\hline Day & $\begin{array}{c}\text { \% Gd labelled cells } \\
\text { observed }\end{array}$ & $\begin{array}{c}\text { Average signal } \\
\text { I counts }\end{array}$ \\
\hline 1 & 100 & 4118 \\
2 & 100 & 3296 \\
3 & 100 & 2901 \\
4 & 99.6 & 2959 \\
5 & 100 & 2744 \\
6 & 100 & 2473 \\
7 & 99.6 & 2220 \\
10 & 98.8 & 2014 \\
\hline
\end{tabular}

Table 4. The percentage of Gd labelled cells in ex-vivo mouse lavage samples, following infusion of 5 million $\mathrm{Gd}$ labelled human $\mathrm{CD}^{+}$cells. Individual cells ( 250 per sample) were analysed by LA-ICP-MS. Labelled cells were identified on the basis of their ${ }^{157} \mathrm{Gd}$ signal. Human cell reconstitution was determined by flow cytometry (BD FACSCanto, BD Biosciences).

\begin{tabular}{cccc}
\hline Mouse & Day & $\begin{array}{c}\text { \% Gd positive cells } \\
\text { (by LA-ICP-MS) }\end{array}$ & $\begin{array}{c}\text { Human cell reconstitution } \\
\text { (by flow cytometry) }\end{array}$ \\
\hline 1 & 3 & 13.2 & not detected \\
2 & 3 & 66.4 & positive \\
3 & 3 & 14.0 & not detected \\
\hline 4 & 6 & 2.0 & not detected \\
5 & 6 & 35.6 & positive \\
6 & 6 & 48.4 & positive \\
\hline 7 & 10 & 20.4 & positive \\
8 & 10 & 49.2 & positive \\
\hline
\end{tabular}


FIGURES
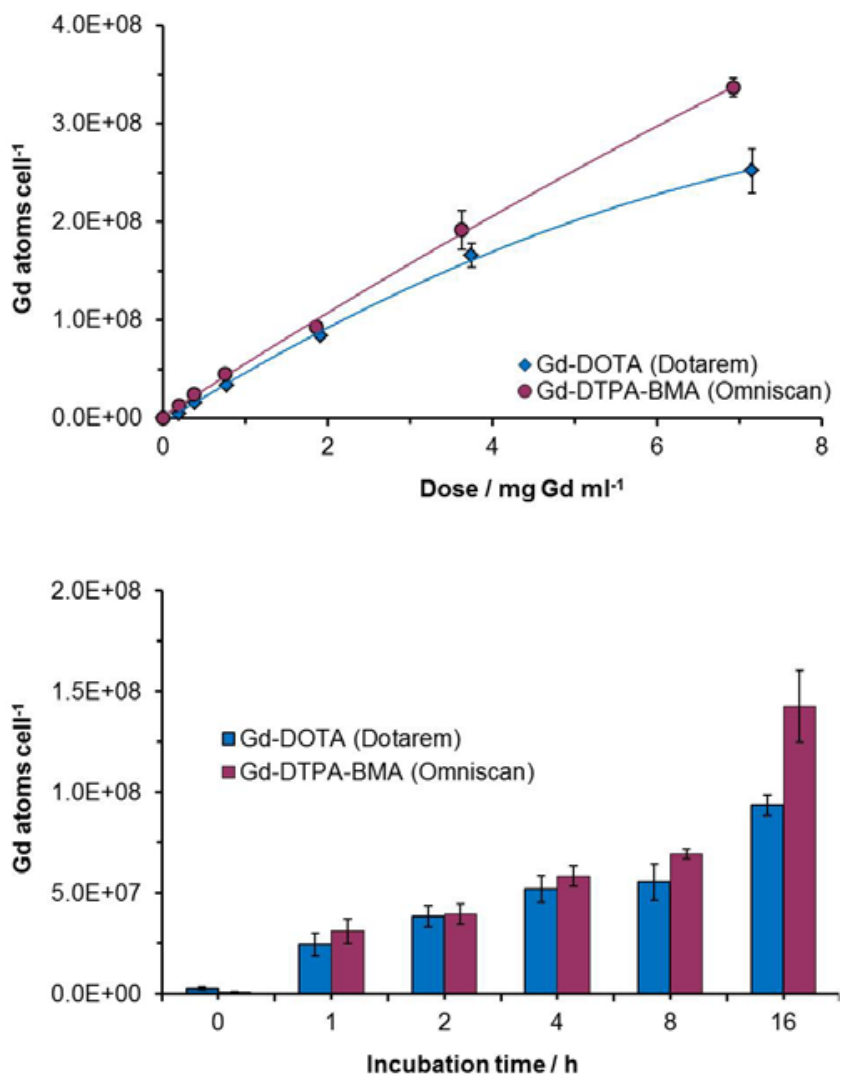

Figure 1. The relationship between the dose of Gd-DOTA and Gd-DTPA-BMA (top) and the incubation time (bottom) on the uptake of $\mathrm{Gd}$ atoms by human $\mathrm{CD} 4^{+} \mathrm{T}$ cells. Uptake was determined using solution based ICP-MS. Error bars show the standard error of the mean.

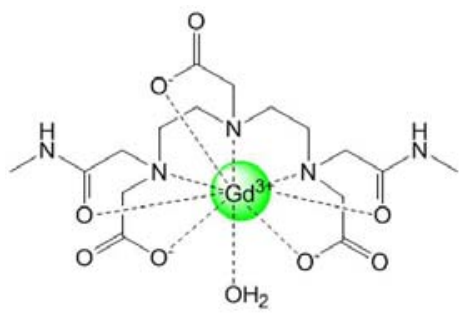

Gd-DTPA-BMA (Omniscan®)

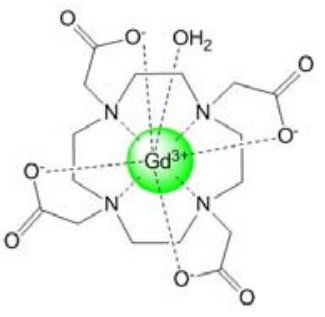

Gd-DOTA'-

(Dotarem®)

Figure 2. Structures of the commercially available contrast agents used for cell labelling. 

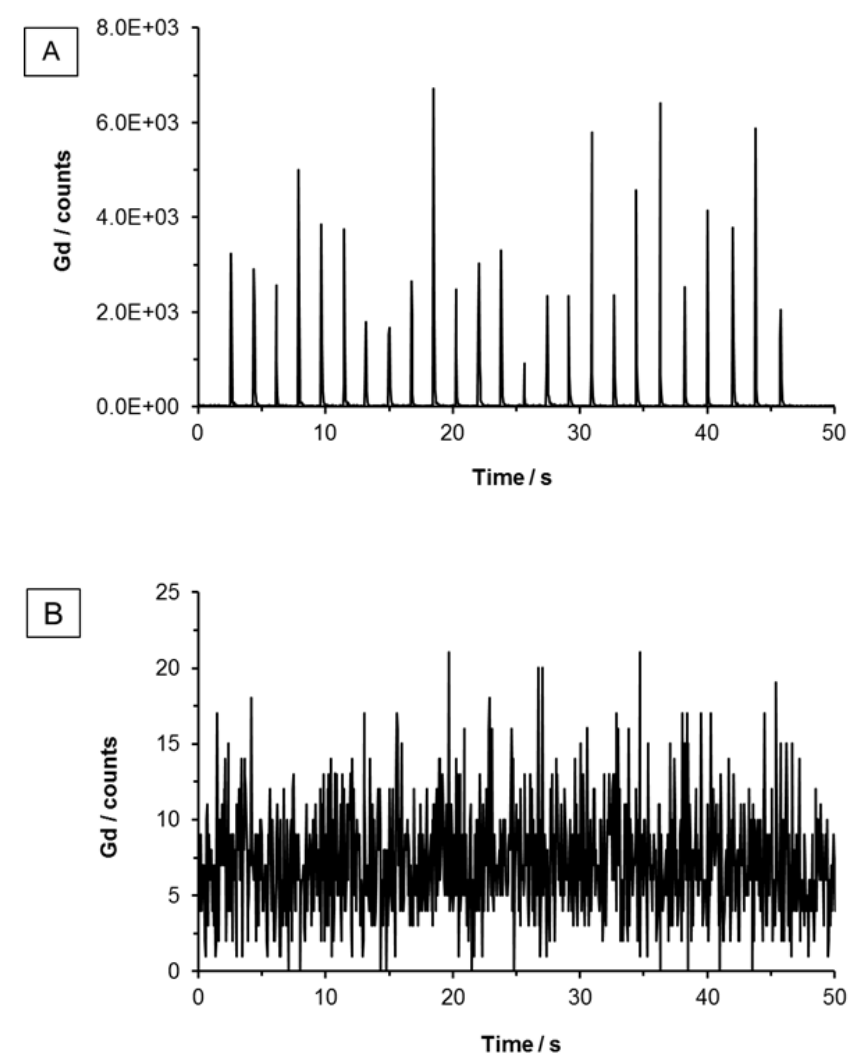

Figure 3. Signal intensities obtained when performing LA-ICP-MS on A) 25 single Gd-DTPABMA labelled human $\mathrm{CD}^{+} \mathrm{T}$ cells and B) 25 single non-labelled human $\mathrm{CD} 4^{+} \mathrm{T}$ cells.

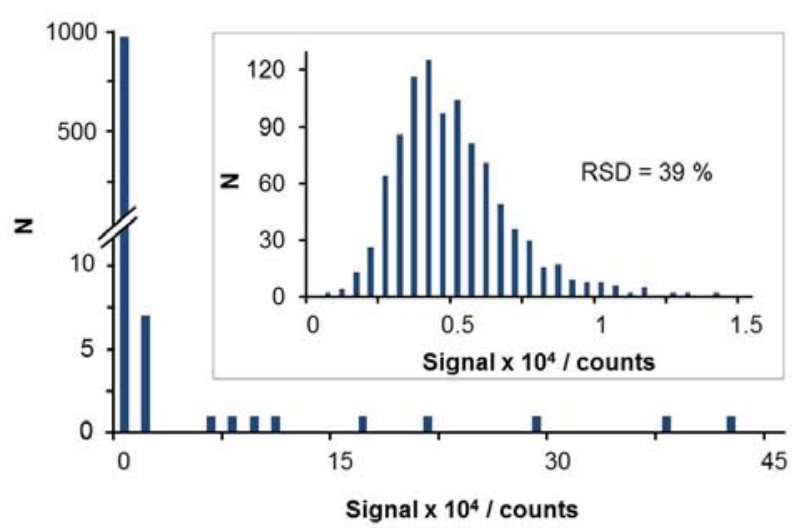

Figure 4. Histogram showing the distribution of ${ }^{157} \mathrm{Gd}$ signal intensities for the ablation of $1000 \mathrm{Gd}$ labelled cells. It is speculated that the human CD4+ cells $(97.2 \%$ pure in the total cell population) are present within the first peak, with signals outside this range $(1.6 \%$ of the signals observed) corresponding to the ablation of phagocytic monocytes. The inset shows expanded view of the distribution within the first peak. 

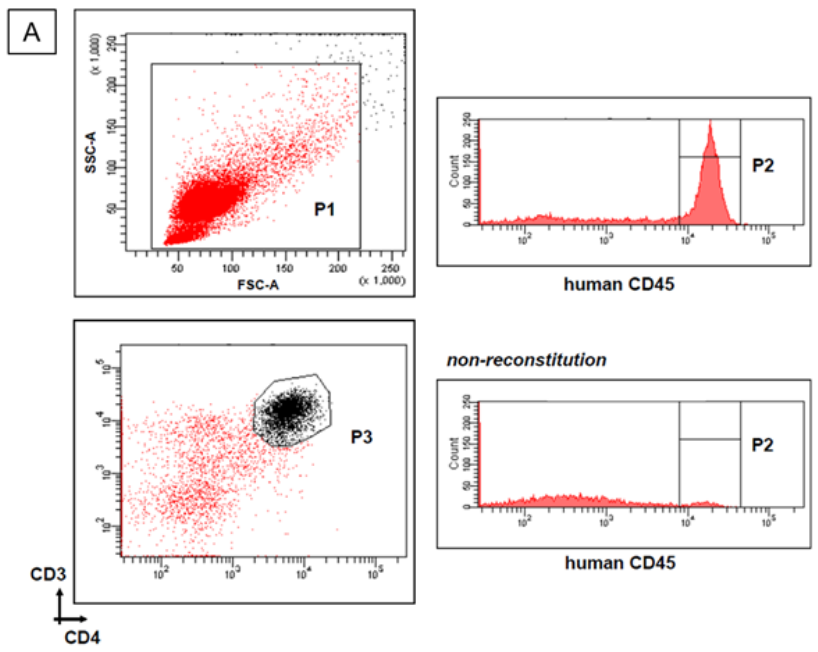

non-reconstitution

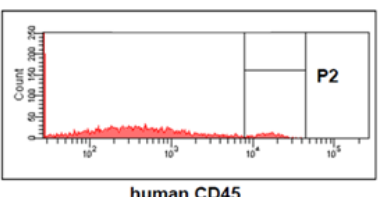

human CD45

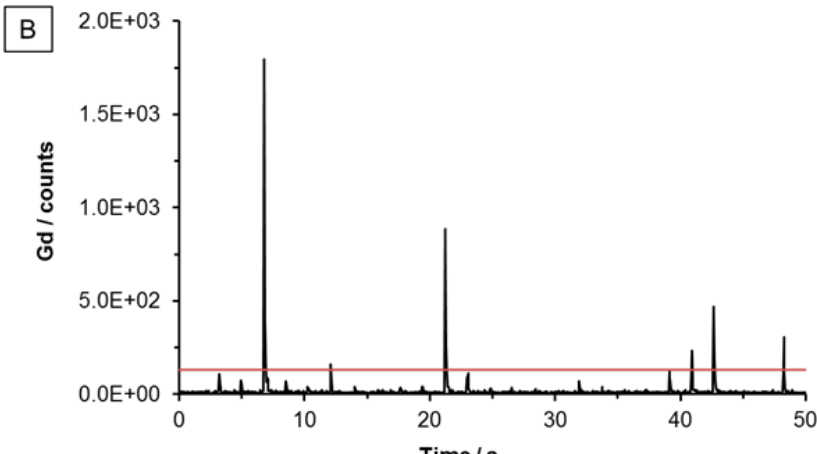

Figure 5. Human $\mathrm{CD}^{+} \mathrm{T}$ cells (purity $97.2 \%$ ) were labelled with Gd-DTPA-BMA, washed extensively and administered intraperitonealy $\left(2 \times 10^{6}\right)$ to $B A L B / c$ immunodeficient mice together with $3 \times 10^{6}$ autologous PBMC. Peritoneal lavage samples were collected for flow cytometry (A) and LA-ICP-MS analysis (B).

5A - day 6 lavage data: one of three mice shown; upper left panel - leucocyte gate; upper right panel - readily detected human $\mathrm{CD}^{+} 5^{+}$cells (P2 gate); lower left panel, human $\mathrm{CD}^{+} \mathrm{CD}^{+} \mathrm{T}$ cells within the gated $\mathrm{CD} 45^{+}$population confirming $\mathrm{CD} 4^{+} \mathrm{T}$ cell reconstitution. For comparison, lower right panel shows another of the three mice with no evidence of human cell reconstitution.

5B - Example data from the reconstituted lavage shown in $5 \mathrm{~A}$ - (day 6 , mouse 5 lavage), showing the presence of $6 \mathrm{Gd}$ labelled cells. Small peaks below the threshold value (red line) were not included in the \% labelled count. 


\section{REFERENCES}

(1) Trzonkowski, P.; Bieniaszewska, M.; Juscinska, J.; Dobyszuk, A.; Krzystyniak, A.; Marek, N.; Mysliwska, J.; Hellmann, A. Clin. Immunol. 2009, 133, 22-26.

(2) Brunstein, C. G.; Miller, J. S.; Cao, Q.; McKenna, D. H.; Hippen, K. L.; Curtsinger, J.; DeFor, T.; Levine, B. L.; June, C. H.; Rubinstein, P.; McGlave, P. B.; Blazar, B. R.; Wagner, J. E. Blood 2011, 117, 1061-1070.

(3) Di lanni, M.; Falzetti, F.; Carotti, A.; Terenzi, A.; Castellino, F.; Bonifacio, E.; Del Papa, B.; Zei, T.; Ostini, R. I.; Cecchini, D.; Aloisi, T.; Perruccio, K.; Ruggeri, L.; Balucani, C.; Pierini, A.; Sportoletti, P.; Aristei, C.; Falini, B.; Reisner, Y.; Velardi, A.; Aversa, F.; Martelli, M. F. Blood 2011, 117, 3921-3928.

(4) Marek-Trzonkowska, N.; Mysliwiec, M.; Dobyszuk, A.; Grabowska, M.; Techmanska, I.; Juscinska, J.; Wujtewicz, M. A.; Witkowski, P.; Mlynarski, W.; Balcerska, A.; Myslinwska, J.; Trzonkowski, P. Diabetes Care 2012, 35, 1817-1820.

(5) Sakaguchi, S.; Yamaguchi, T.; Nomura, T.; Ono, M. Cell 2008, 133, 775-787.

(6) McMurchy, A. N.; Bushell, A.; Levings, M. K.; Wood, K. J. Seminars in Immunology 2011, 23, 304-313.

(7) Wood, K. J.; Bushell, A.; Hester, J. Nature Reviews Immunology 2012, 12, 417-430.

(8) Groux, H.; Ogarra, A.; Bigler, M.; Rouleau, M.; Antonenko, S.; deVries, J. E.; Roncarolo, M. G. Nature 1997, 389, 737-742.

(9) Battaglia, M.; Gregori, S.; Bacchetta, R.; Roncarolo, M. G. Seminars in Immunology 2006, 18, 120-127.

(10) Peche, H.; Trinite, B.; Martinet, B.; Cuturi, M. C. Am. J. Transplant. 2005, 5, 255-267.

(11) Hutchinson, J. A.; Riquelme, P.; Sawitzki, B.; Tomiuk, S.; Miqueu, P.; Zuhayra, M.; Oberg, H. H.; Pascher, A.; Lutzen, U.; Janssen, U.; Broichhausen, C.; Renders, L.; Thaiss, F.; Scheuermann, E.; Henze, E.; Volk, H. D.; Chatenoud, L.; Lechler, R. I.; Wood, K. J.; Kabelitz, D.; Schlitt, H. J.; Geissler, E. K.; Fandrich, F. J. Immunol. 2011, 187, 2072-2078.

(12) Riquelme, P.; Tomiuk, S.; Kammler, A.; Fandrich, F.; Schlitt, H. J.; Geissler, E. K.; Hutchinson, J. A. Mol. Ther. 2013, 21, 409-422.

(13) Kamaly, N.; Miller, A. D. Int. J. Mol. Sci. 2010, 11, 1759-1776.

(14) Shyu, W. C.; Chen, C. P.; Lin, S. Z.; Lee, Y. J.; Li, H. Stroke 2007, 38, 367-374.

(15) Guenoun, J.; Koning, G. A.; Doeswijk, G.; Bosman, L.; Wielopolski, P. A.; Krestin, G. P.; Bernsen, M. R. Cell transplantation 2012, 21, 191-205.

(16) Kalliokoski, T.; Svedström, E.; Saunavaara, J.; Roivainen, A.; Kankaanpää, M.; Oivanen, H.; Nuutila, P.; Simell, O. Advances in Molecular Imaging 2011, 1, 43-49.

(17) Becker, J. S.; Zoriy, M.; Matusch, A.; Wu, B.; Salber, D.; Palm, C. Mass Spectrom. Rev. 2010, 29, 156-175.

(18) Feldmann, J.; Kindness, A.; Ek, P. J. Anal. At. Spectrom. 2002, 17, 813-818.

(19) Kindness, A.; Sekaran, C. N.; Feldmann, J. Clin. Chem. 2003, 49, 1916-1923.

(20) Jackson, B.; Harper, S.; Smith, L.; Flinn, J. Anal. Bioanal. Chem. 2006, 384, 951-957.

(21) Dehnhardt, M.; Zoriy, M.; Khan, Z.; Reifenberger, G.; Ekstrom, T.; Becker, J. S.; Zilles, K.; Bauer, A. Journal of Trace Elements in Medicine and Biology 2008, 22, 17-23.

(22) Hare, D.; Reedy, B.; Grimm, R.; Wilkins, S.; Volitakis, I.; George, J. L.; Cherny, R. A.; Bush, A. I.; Finkelstein, D. I.; Doble, P. Metallomics 2009, 1, 53-58.

(23) Hare, D. J.; George, J. L.; Grimm, R.; Wilkins, S.; Adlard, P. A.; Cherny, R. A.; Bush, A. I.; Finkelstein, D. I.; Doble, P. Metallomics 2010, 2, 745-753.

(24) Matusch, A.; Depboylu, C.; Palm, C.; Wu, B.; Hoglinger, G. U.; Schafer, M. K. H.; Becker, J. S. J. Am. Soc. Mass Spectrom. 2010, 21, 161-171.

(25) Neilsen, J. L.; Abildtrup, A.; Christensen, J.; Watson, P.; Cox, A.; McLeod, C. W. Spectroc. Acta Pt. B-Atom. Spectr. 1998, 53, 339-345.

(26) Giesen, C.; Waentig, L.; Mairinger, T.; Drescher, D.; Kneipp, J.; Roos, P. H.; Panne, U.; Jakubowski, N. J. Anal. At. Spectrom. 2011, 26, 2160-2165. 
(27) Drescher, D.; Giesen, C.; Traub, H.; Panne, U.; Kneipp, J.; Jakubowski, N. Anal. Chem. 2012, 84, 9684-8.

(28) Hsieh, Y. K.; Jiang, P. S.; Yang, B. S.; Sun, T. Y.; Peng, H. H.; Wang, C. F. Anal. Bioanal. Chem. 2011, 401, 909-915.

(29) Kamaly, N.; Pugh, J. A.; Kalber, T. L.; Bunch, J.; Miller, A. D.; McLeod, C. W.; Bell, J. D. Molecular Imaging and Biology 2010, 12, 361-366.

(30) Pugh, J. A. T.; Cox, A. G.; McLeod, C. W.; Bunch, J.; Writer, M. J.; Hart, S. L.; Bienemann, A.; White, E.; Bell, J. Anal. Bioanal. Chem. 2012, 403, 1641-1649.

(31) Horstwood, M. S. A.; Foster, G. L.; Parrish, R. R.; Noble, S. R.; Nowell, G. M. J. Anal. At. Spectrom. 2003, 18, 837-846.

(32) Yamada, K.; Kato, N.; Takagi, A.; Koi, M.; Hemmi, H. Anal. Bioanal. Chem. 2005, 382, $1702-1707$.

(33) Kerr, S. L. Ph.D. Thesis, Loughborough University, 2008.

(34) Terreno, E.; Crich, S. G.; Belfiore, S.; Biancone, L.; Cabella, C.; Esposito, G.; Manazza, A. D.; Aime, S. Magn. Reson. Med. 2006, 55, 491-497.

(35) Di Gregorio, E.; Gianolio, E.; Stefania, R.; Barutello, G.; Digilio, G.; Aime, S., Anal. Chem. 2013, DOI: 10.1021/ac400973q.

(36) Idee, J. M.; Port, M.; Robic, C.; Medina, C.; Sabatou, M.; Corot, C. J. Magn. Reson. Imaging 2009, 30, 1249-1258.

(37) Robic, C.; Catoen, S.; Goltstein, D. M.-C.; Idee, J.-M.; Port, M. Biometals 2011, 24, 759-768.

(38) Cheng, Y.; Yao, H. Y.; Lin, H. K.; Lu, J. F.; Li, R. C.; Wang, K. Chem.-Biol. Interact. 1999, 121, 267-289.

(39) Nadig, S. N.; Wieckiewicz, J.; Wu, D. C.; Warnecke, G.; Zhang, W.; Luo, S.; Schiopu, A.; Taggart, D. P.; Wood, K. J. Nature Medicine 2010, 16, 809-U112.

(40) Issa, F.; Hester, J.; Goto, R.; Nadig, S. N.; Goodacre, T. E.; Wood, K. Transplantation 2010, 90, 1321-1327.

(41) Cowper, S. E.; Robin, H. S.; Steinberg, S. M.; Su, L. D.; Gupta, S.; LeBoit, P. E. Lancet 2000, 356, 1000-1001.

(42) Grobner, T. Nephrol. Dial. Transplant. 2006, 21, 1104-1108.

(43) Marckmann, P.; Skov, L.; Rossen, K.; Dupont, A.; Damholt, M. B.; Heaf, J. G.; Thomsen, H. S. J. Am. Soc. Nephrol. 2006, 17, 2359-2362.

(44) www.onestudy.org (accessed 04/05/12). 


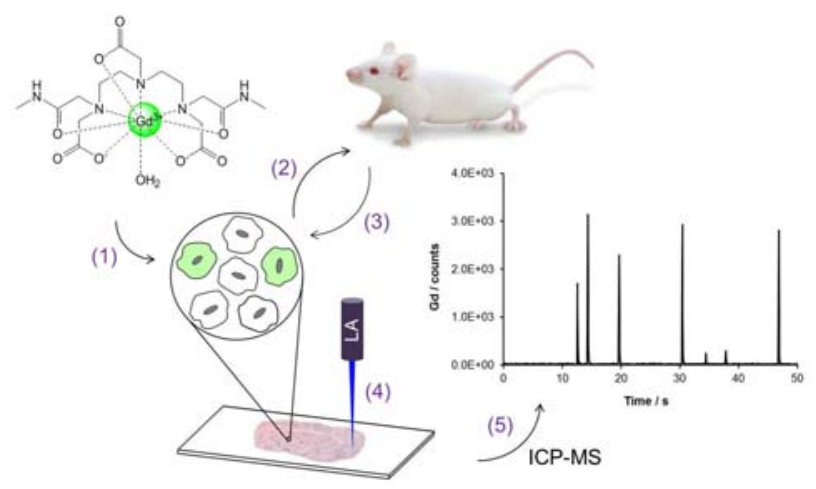

For TOC only 